\title{
The Relation of Matrix Metalloproteinase 1, 2, 3 Expressions with Clinical and Radiological Findings in Primary and Recurrent Lumbar Disc Herniations
}

\author{
Primer ve Nüks Lomber Disk Hernilerinde Matriks Metalloproteinaz \\ 1, 2 ve 3 Ekspresyonlarının Klinik ve Radyolojik Bulgularla İlişkisi
}

Seyma OZKANLI ${ }^{1}$, Tuncay KANER ${ }^{2}$, Mustafa EFENDIOGLU ${ }^{3}$, Recep BASARAN ${ }^{3}$, Mehmet SENOL $^{2}$, Ebru ZEMHERI ${ }^{1}$, Ahmet Ferruh GEZEN ${ }^{2}$

${ }_{1}^{1}$ Istanbul Medeniyet University, Goztepe Training and Research Hospital, Department of Pathology, Istanbul, Turkey

${ }^{2}$ Istanbul Medeniyet University, Goztepe Training and Research Hospital, Department of Neurosurgery, Istanbul, Turkey

${ }^{3}$ Dr. Lutfi Kirdar Kartal Training and Research Hospital, Department of Neurosurgery, Istanbul, Turkey

Corresponding Author: Tuncay KANER / E-mail: tuncaykaner@gmail.com

\begin{abstract}
AIM: In this study, our aim was to examine if matrix metalloproteinase expressions (MMP-1, MMP-2, MMP-3) in patients operated with a lumbar disc hernia diagnosis are different in terms of clinical and neuroradiological findings.

MATERIAL and METHODS: The study included 80 patients treated with micro discectomy for lumbar disc hernia. Degeneration was scored via magnetic resonance (MR) images. MMP-1, MMP-2, and MMP-3 antibodies were used for immunohistochemical evaluation of degenerated disc materials. MMP expressions were compared between primary and recurrent cases, and correlation analysis was conducted.

RESULTS: Discectomy material showed higher expression of MMP-1 and MMP-3 in cases of recurrent lumbar disc herniation than in primary herniation. There was no significant relationship between MMP expression and MR degeneration score.

CONCLUSION: MMP-1 and MMP-3 expressions were significantly higher in recurrent cases in terms of magnetic resonance degeneration score. We assume that the higher co-expression of MMP-1 and MMP-3 might be used in targeted treatment regiemens in patients with recurrent LDH. KEYWORDS: Lumbar disc herniation, Matrix metalloproteinase, Pfirrmann classification, Recurrent disc herniation
\end{abstract}

öz

AMAÇ: Çalışmada primer ve nüks lomber disk hernisi (LDH) tanısı ile ameliyat edilen hastalarda matriks metalloproteinaz (MMP-1, MMP-2, MMP-3) ekspresyonlarının değişik klinik ve nöroradyolojik bulgularla karşılaştırılması amaçlandı.

YÖNTEM ve GEREÇLER: Hastanemizde LDH tanısı ile mikrodiskektomi uygulanan 80 olgu çalışmaya dahil edildi. İntervertebral alandan alınan dejenere disk materyali patoloji kliniğinde histokimyasal olarak Hematoksilen-Eozin boyası ile değerlendirildikten sonra MMP-1, MMP-2 ve MMP-3 antikorları kullanılarak immünohistokimyasal inceleme yapılmıştır. MMP ekspresyonları primer ve rekürren olgularda karşılaştırılıp, korelasyon analizi yapılmıştır.

BULGULAR: MMP-1 ve MMP-3 ekspresyonu nüks olgularda primer olanlara göre daha yüksek bulunmuştur. MMP ekspresyonu ile MR dejenerasyon skoru arasında anlamlı bir ilişki yoktur.

SONUÇ: Nüks lomber disk hernilerinde MMP-1 ve MMP-3 ekspresyonu primer olgulara göre istatistiksel olarak anlamlı yüksek bulunmuştur. MMP-1 ve MMP-3, LDH'lu olgularda yüksek oranda ekspresyonunun hedef tedavi protokollerinde kullanılabileceğini düşünmekteyiz.

ANAHTAR SÖZCÜKLER: Lomber disk herniasyonu, Matriks metalloproteinaz, Pfirrmann sınıflaması, Nüks disk herniasyonu

\section{INTRODUCTION}

Degenerative disc disease (DDD) is a clinical condition such as disc hernia, spondylosis, and radiculopathy. It is generally seen in parts of the vertebrae exposed to stress, and is caused by biochemical, vascular, and anatomic changes in intervertebral discs. Intervertebral discs (IVD) are composed of annulus fibrosus and nucleus pulposus, and have an elastic structure that transfers compressive load to the spinal column. The structure of the extracellular matrix (ECM) of the discs comprises collagen, proteoglycans, and water. The unity of this structure determines the functional features of the intervertebral disc. In conditions such as degenerative disc disease and disc hernia, these important structural components of the extracellular matrix are denatured and disorganized 
$(4,14)$. During intervertebral disc degeneration, the balance between ECM synthesis and destruction is lost. Matrix metalloproteinases (MMPs) are zinc- and calcium-dependent endopeptidases that contribute substantially to this balance, helping restore connective tissue during physiological and pathologic stages (16). It was reported that MMPs are significantly important in IVD degeneration. MMP expression occurs in response to conditions such as mechanical stress and inflammation (23). As a result of the degeneration of biomechanical features of the intervertebral disc, acute and chronic pain occurs $(5,8)$. Cytokines such as TNF-a, IL- $1 a$, and substance $P$ and neurokinins are significantly important in the development of chronic lumbar pain and radicular pain $(1,3,19,20)$. These cytokines stimulate the synthesis of MMP-3 protease (12).

This study compared the clinical and neuroradiological findings with MMP-1, MMP-2, and MMP-3 expressions in patients operated for primary or recurrent lumbar disc herniation (LDH).

\section{MATERIAL and METHODS}

This retrospective study includes 80 patients who presented to the neurosurgery department with lumbar pain and/or leg pain, and who were treated with micro discectomy following diagnosis of lumbar disc herniation. The Istanbul Medeniyet University Goztepe Research and Training Hospital Ethics Committee approved this study (2014/0091).

Magnetic resonance imaging (MRI) was used to evaluate the extent disc of degeneration according to the five-level Pfirrmann grading system (15).

Degenerated material was removed from the herniated intervertebral disc by micro discectomy, and was evaluated both histochemically with hematoxylin-eosin staining, and immunohistochemically using MMP-1, MMP-2, and MMP-3 antibodies. Sections of $3 \mu \mathrm{m}$ were taken from selected paraffin blocks that were previously coated with poly-L-lysine. Specimen slides were then deparaffinized with xylene for $10 \mathrm{~min}$. Sections of $3 \mu \mathrm{m}$ were taken from selected paraffin blocks and rehydrated. Hydrogen peroxide, phosphate buffered saline (PBS), and a nonspecific blocking reagent (Ultra $\mathrm{V}$ block: ScyTek Laboratories, USA) were applied as antigen retrieval solutions. Rabbit MMP-1, MMP-2, and MMP-3 antibodies (SPRING Biotechnology, Inc. Europe) were then localized at room temperature for approximately $90 \mathrm{~min}$ at dilutions of 1:200, 1:100, and 1:50 (MMP-1, MMP-2, MMP-3), respectively. After incubation with primary reagents, the slides were incubated with Ultra Tek anti-polyvalent biotinylated antibody (ScyTek Laboratories) as the secondary antibody for $15 \mathrm{~min}$. After rehydration, Ultra Tek HRP (ScyTek Laboratories) was added to the specimens. After rehydration with PBS, the DAB chromogen system (DAB substrate kit, ScyTek Laboratories) was added to the specimens. Slides were counterstained with hematoxylin. Cytoplasmic staining was accepted as positive. The findings were evaluated via quantitative morphometric analysis.
The immunohistochemically-stained sections were examined using a light microscope (Olympus BX-51). The staining score each of the three antibodies was specified in percentages (\%) by determining the number of positively-stained cells per 100 cells. Statistical analysis was performed using SPSS software (version 11) as follows: Student's t-test for normally distributed numeric variables; Mann-Whitney u-test for non-parametric comparison; chi-square test for categorical variables; and Pearson's correlation analysis using a significance level of $p<0.05$.

\section{FINDINGS}

The group comprised 47 (58.75\%) male and 33 (41.25\%) female patients. Average age was $51.1 \pm 12.7$ (range 20-85) years. The complaint was present on the right side in 37 (46.3\%) patients, on the left side in 39 (48.8\%) patients and on both sides in 4 (5\%) patients. Forty-three $(53.8 \%)$ of the 80 cases were primary and $37(46.3 \%)$ were recurrent. Deficits comprised loss of strength in extensor halluces in $16(20 \%)$ cases, loss of strength in tibialis anterior in $8(10 \%)$, and fecal incontinence in 2 (2.5\%) patients (Table I).

Following assessment of MR images, one (1.3\%) case was classified as grade 2, six (7.5\%) as grade 3, forty-eight (60\%) as grade 4 , and twenty-one (26.3\%) cases were classified as grade 5 (Figure 5). No MR scoring was performed in four cases. When all cases were assessed, the average MMP-1 (Figure 1) value was $50.0 \pm 22.4$, average MMP-2 (Figure 2) value was $74.3 \pm 22.2$, and average MMP-3 (Figure 3) value was 78.0 \pm 17.8 . MR degeneration score and MMP value were similar in men and women; in addition, there was no significant difference between men and women in terms of any variables ( $p>0.05)$.

Comparison of primary and recurrent LDH patients showed no significant difference in terms of gender, operational direction, operational level, presence of deficit, MR degeneration score, age, or complaint duration ( $p>0.05$ ). When primary and recurrent groups were compared, MMP expression was more apparent in recurrent cases, and the difference was significant

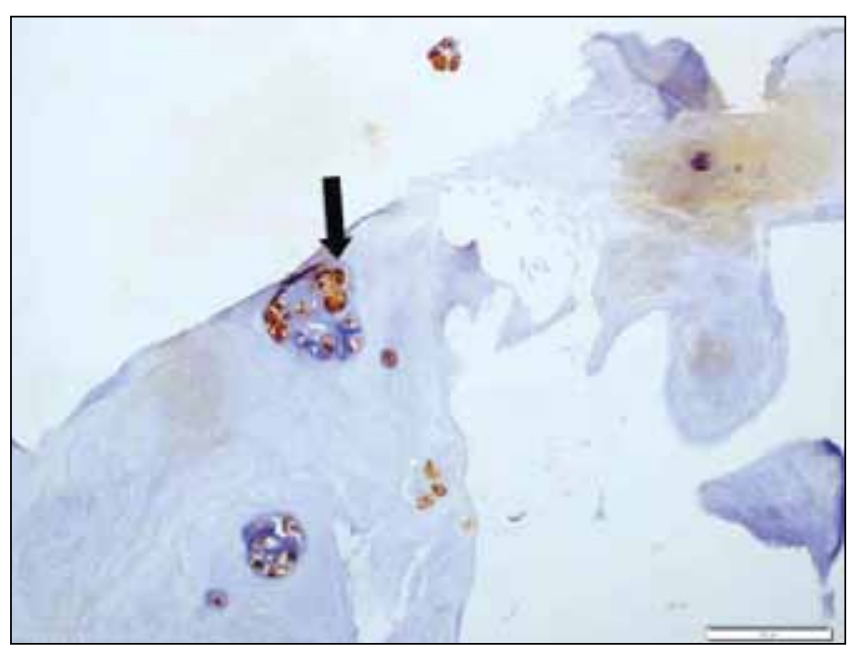

Figure 1: Positive cytoplasmic-nuclear staining with MMP-1in chondrocytes in nucleus pulposus (arrow) (H\&Ex200). 
for MMP-1 and MMP-3 values (Table II) (Figure 6). The MR degeneration score was similar in cases of primary and recurrent disc hernia $(p=0.850)$.

No correlation was found between complaint period and MR degeneration score and MMP values, or between magnetic resonance degeneration score and any of the three MMP values. There was a weak positive correlation between age and MMP-1 $(r=221, p=0.049)$. Patients were grouped by age $(\leq 40$; 41 to $60 ;>61)$ and the correlation analyses were repeated.
The $\leq 40$ group showed a stronger correlation between MMP1 and age $(r=0.754 ; p=0.002)$ and a significant correlation between MMP-2 and age ( $r=0.533 ; p=0.050)$ (Figure 4).

\section{DISCUSSION}

The intervertebral disc is an interface between two vertebrae, consisting of an outer annulus fibrosus and an inner nucleus pulposus. It functions as a (wall) tamp against the pressure induced by upper body weight, and contributes to the

Table I: Patient Characteristics for Primary and Recurrent Groups

\begin{tabular}{|c|c|c|c|}
\hline & & Primary & Recurrent \\
\hline Woman & & $22(51.2 \%)$ & $11(29.7 \%)$ \\
\hline Operational direction & $\begin{array}{l}\text { Right } \\
\text { Left }\end{array}$ & $\begin{array}{l}18(48.6 \%) \\
19(51.4 \%)\end{array}$ & $\begin{array}{l}16(45.7 \%) \\
19(54.3 \%)\end{array}$ \\
\hline Operational level & $\begin{array}{l}\text { L3-L4 } \\
\text { L4-L5 } \\
\text { L5-S1 }\end{array}$ & $\begin{array}{r}5(11.9 \%) \\
21(50.0 \%) \\
16(38.1 \%)\end{array}$ & $\begin{array}{c}1(2.7 \%) \\
28(75.7 \%) \\
8(21.6 \%)\end{array}$ \\
\hline MR degeneration score & $\begin{array}{l}\text { Grade } 2 \\
\text { Grade } 3 \\
\text { Grade } 4 \\
\text { Grade } 5\end{array}$ & $\begin{array}{c}0 \\
4(9.8 \%) \\
26(63.4 \%) \\
11(26.8 \%)\end{array}$ & $\begin{array}{c}1(2.9 \%) \\
2(5.7 \%) \\
22(62.9 \%) \\
10(28.6 \%)\end{array}$ \\
\hline Neurological Deficit & & $11(29.7 \%)$ & $15(42.9 \%)$ \\
\hline Complaint period (month) & & $21.8 \pm 46.6$ & $10.4 \pm 17.2$ \\
\hline Age (year) & & $48.7 \pm 14.1$ & $53.8 \pm 10.4$ \\
\hline
\end{tabular}

Table II: MMP Levels in Primary and Recurrent Groups

\begin{tabular}{|c|c|c|c|} 
& $\begin{array}{c}\text { Primary LDH } \\
n=43\end{array}$ & $\begin{array}{c}\text { Recurrent LDH } \\
n=37\end{array}$ & 0.007 \\
\hline MMP-1 & $50.9 \pm 23$ & $64.1 \pm 20.0$ & 0.421 \\
\hline MMP-2 & $72.4 \pm 24.7$ & $76.5 \pm 19.1$ & 0.001 \\
\hline MMP-3 & $72.2 \pm 16.1$ & $84.8 \pm 17.5$ & 0 \\
\hline
\end{tabular}

LDH: lumbar disc herniation, MMP: matrix metalloproteinase expressions.

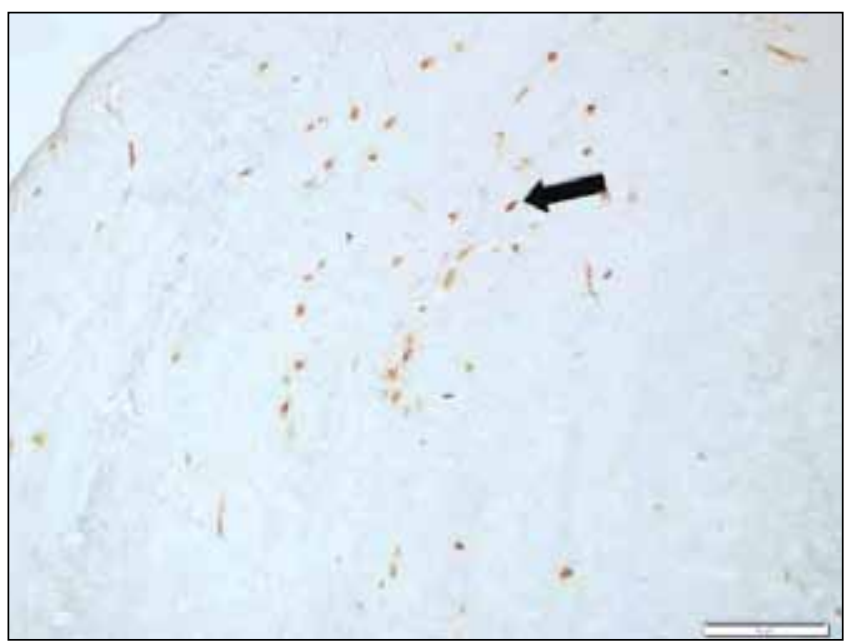

Figure 2: Chondrocytes positively stained with MMP-2 in nucleus pulposus (arrow) (H\&E x200).

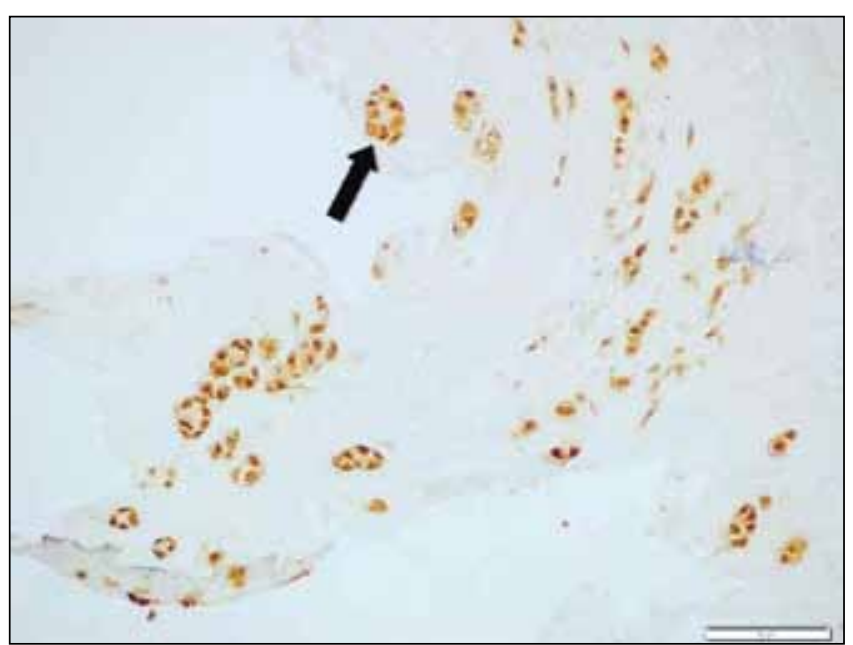

Figure 3: Positive cytoplasmic-nuclear staining with MMP-3 in chondrocytes in nucleus pulposus (arrow) (H\&E x200). 


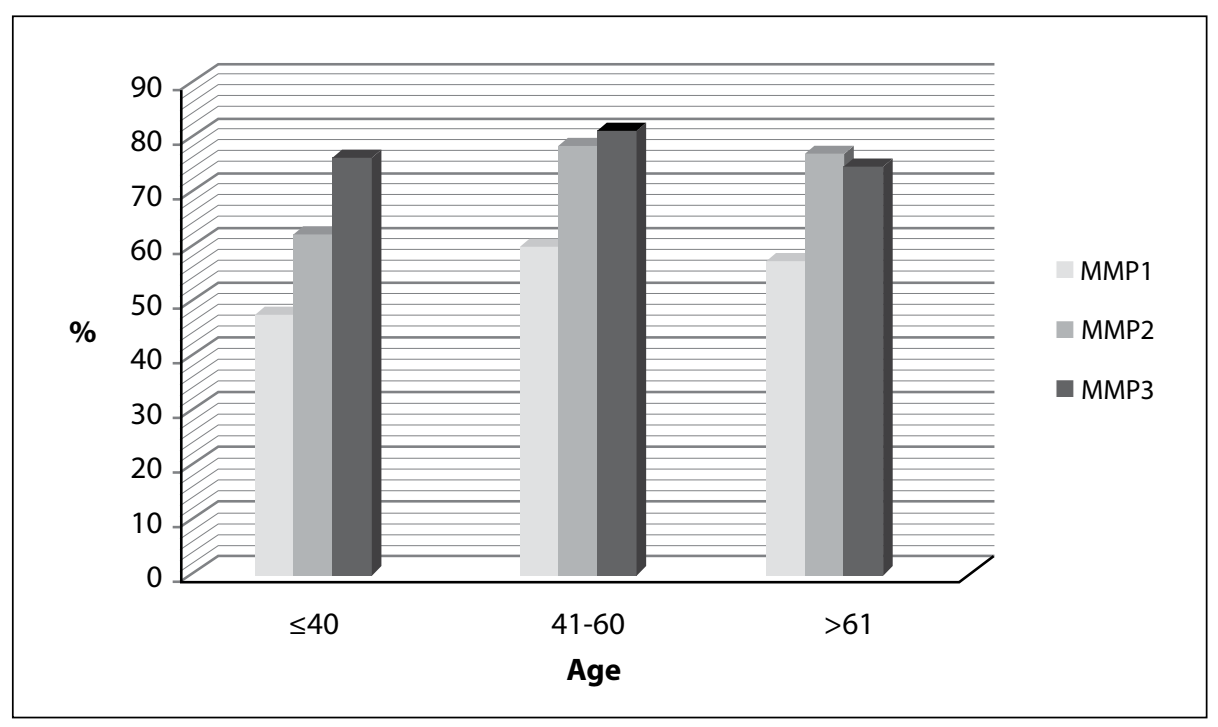

Figure 4: MMP rates according to age.

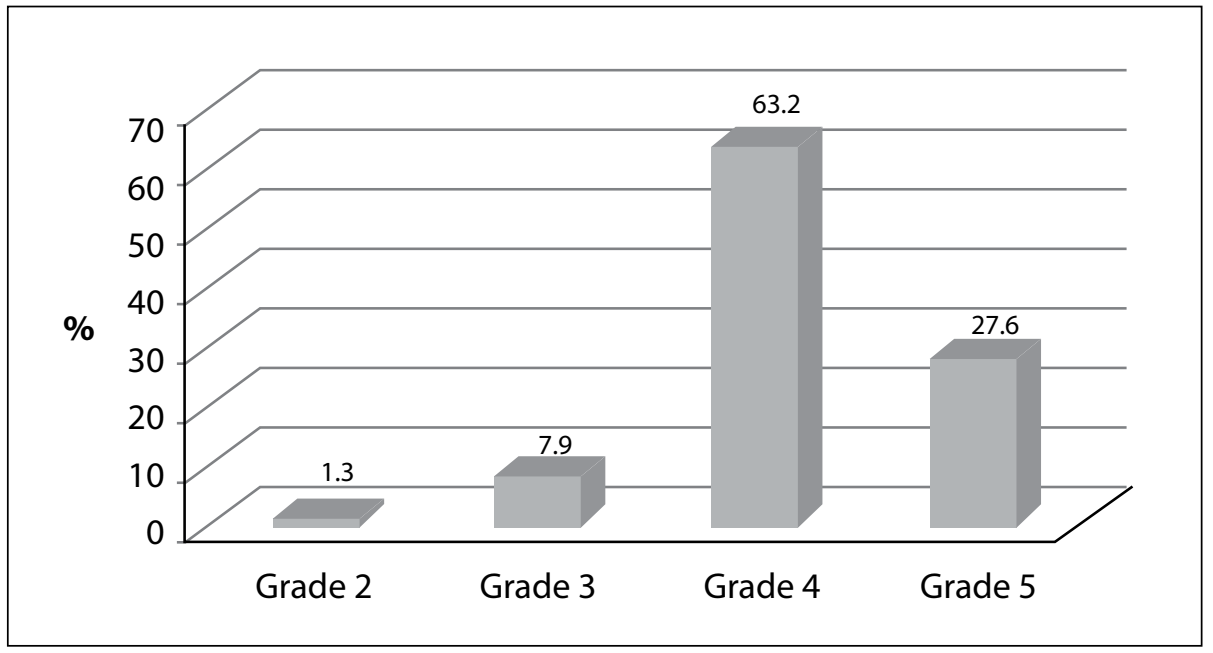

Figure 5: Distribution of cases according to the Pfirrmann classification.

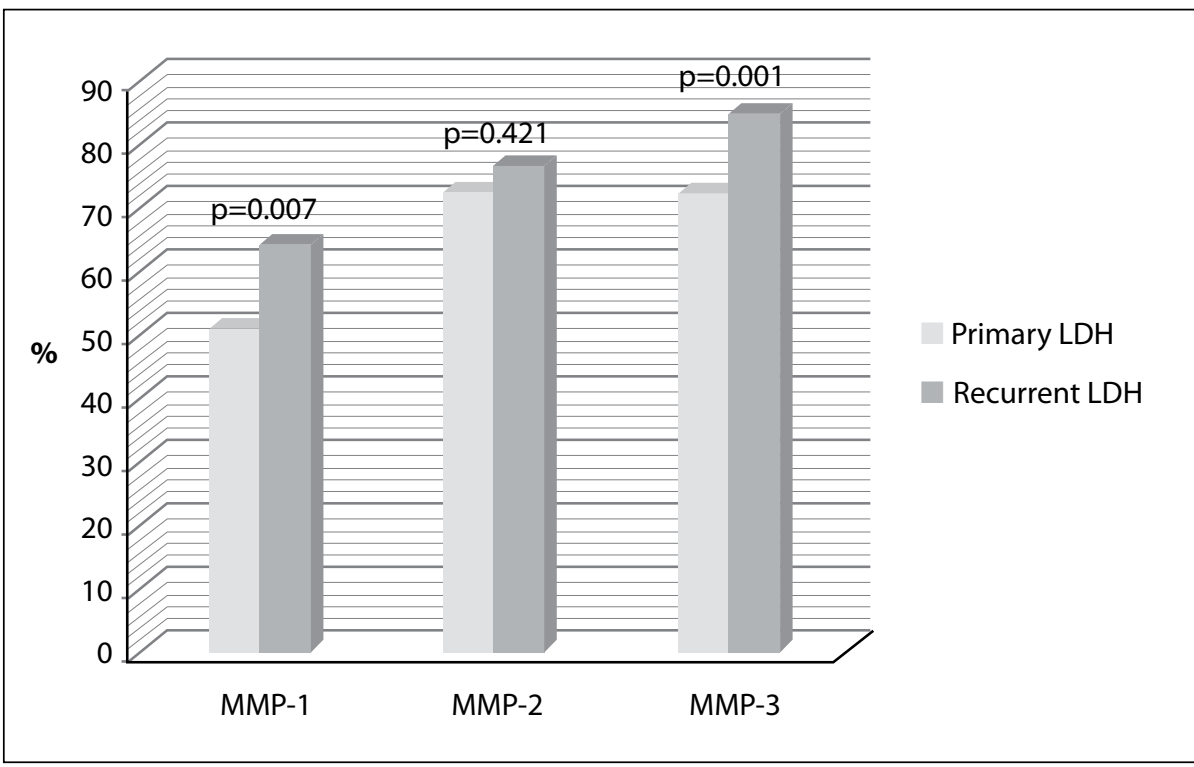

Figure 6: MMP levels in primary and recurrent groups. 
mobility of the vertebral column. Lumbar disc herniation refers to protrusion from the annulus fibrosus by degeneration of the nucleus pulposus, and is an important cause of lumbar leg pain. Factors in the etiology of lumbar disc herniation include age, gender, profession, cigarette smoking, and exposure to vibration (23).

The most important factors in the etiology of disc degeneration are mechanical load and the biomechanical features of the vertebral column. Significant histopathological features of disc degeneration have been reported in many studies: destruction of the collagen mesh and replacement with hyaline collagen fibers, thereby leading to the development of fissures. Additionally, there is statistical evidence that proliferation of chondrocytes inside the disc, the occurrence of lacerations and fissures, and degeneration of the mucoid and granular matrix are related to aging and disc degeneration (13).

The intervertebral disc is mainly composed of type-2 collagen in the nucleus pulposus, whereas the annulus fibrosus is predominantly type- 1 collagen. The structure of these collagens and their interaction has an important role in the mechanical function of the disc. These collagen molecules can only be destroyed by specific enzymes, especially by MMPs. MMPs are the main enzymes in the catabolism of collagen molecules (7, 21).

In a study of cadavers aged from 0 to 86, Weiler et al. reported that MMP-1,-2,-3, and -9 showed significant relationships with age and degeneration (21). Conversely, other studies found no correlation between age and MMP expression (7). In the present study, no significant correlation was found between age and the expression levels of either MMP-2 or MMP-3. There was a weak positive correlation between MMP-1 expression and age $(r=0.221, p=0.049)$.

Recurrent lumbar disc herniation is defined as the onset of symptoms after a six-month pain-free period. Localization can be the same or opposite side as previous occurrences. Etiopathogenesis is attributed to ceasing of annulus during operation, insufficient nucleation of nucleus pulposus, or displacement of a free fragment. Recurrence of lumbar disc herniation was reported as between $3 \%$ and $18 \%(9,10,11)$. In the present study, 37 (46.3\%) of the cases were presented with recurrent $\mathrm{LDH}$. A review of the literature found no previous comparison between patients operated for primary or recurrent LDH in terms of MMP expression and clinical and radiological findings.

Compared with the primary LDH group, recurrent cases showed significantly higher expression of MMP-1 and MMP-3, whereas there was no significant difference in MMP-2 levels. MMP-1 and MMP-3 values are crucial for intervertebral disc status, and so the higher levels observed in recurrent cases indicate more advanced degeneration.

Our results show that primary and recurrent LDH patients were similar in terms of gender, operational direction, and operational level, existence of deficit, age, and complaint period.
MR imaging is the most effective method in the clinical evaluation of intervertebral disc pathologies. T2-weighted MR images showed signal changes related to age and disc degeneration. We used the 5-level Pfirrmann grading system for classification of degeneration observed in MR images. Although degeneration was considered to be higher in recurrent cases, it was interesting that there was no significant inter-group difference in MR degeneration score. Canbay et al. reported that Pfirrmann classification and MR grading provided good non-invasive diagnosis, and emphasized that MR grade was significantly correlated with MMP-3 and histopathological changes. The same study reported no significant relationship between MMP-3 expression and age and symptom period (6).

Zigouris et al. reported a significant correlation between MR herniation grade and MMP-9 in patients aged under 30, but this correlation was not seen in patient groups aged $30-60$ or those over 60 (24). A different lumbar disc herniation study by the same author reported a strong correlation between MMP1 and MMP-3 expressions and the patients' age and herniation grade. In terms of pathogenesis of lumbar disc herniation, the same study reported that MMP-1 expression was higher than that of MMP-3 in the young group of patients (25).

In a controlled study of lumbar disc herniation by Wu et al., MMP-2 expression increased significantly with the progression of disc degeneration as evaluated by MR (22).

In the present study, there was no significant correlation between MR degeneration score and the three MMP values. Additionally, we did not find that complaint period was correlated with MR degeneration score or MMP values. Only MMP-1 showed a weak correlation with age. When the patients were grouped according to age ( $\leq 40,41-60$, and $>61$ ), the $\leq 40$ group showed a significant correlation between age and both MMP-1 $(r=0.754 ; p=0.002)$ and MMP-2 $(r=0.533 ; p=0.050)$.

In today's world, the control of MMP synthesis and activity is a popular way of DDD treatment because MMPs play a role in the development of IVD diseases as shown in previous studies $(5,8,18,23)$. Biologically active and significantly specific MMP inhibitors were produced in the laboratory and it was observed that they inhibited the destruction of cartilage on the animals in vitro $(5,14)$. In conclusion, our findings show that MMP-1 and MMP-3 expressions are higher in lumbar disc recurrence than primary hernia in the discectomy material, and that MMP-1 can be more important in disc degeneration pathogenesis among younger patients.

\section{REFERENCES}

1. Ahn SH, Cho YW, Ahn MW, Jang SH, Sohn YK, Kim HS: mRNA expression of cytokines and chemokines in herniated lumbar intervertebral discs. Spine (Phila Pa 1976) 27: 911- 917, 2002

2. Antoniou J, Steffen $T$, Nelson $F$, Winterbottom $N$, Hollander AP, Poole RA, Aebi M, Alini M: The human lumbar intervertebral disc: Evidence for changes in the biosynthesis and denaturation of the extracellular matrix with growth, maturation, ageing, and degeneration. J Clin Invest 98(4): 996-1003, 1996 
3. Aoki Y, Rydevik B, Kikuchi S, Olmarker K: Local application of disc-related cytokines on spinal nerve roots. Spine (Phila Pa 1976) 27:1614-1617, 2002

4. Boos N, Weissbach S, Rohrbach H, Weiler C, Spratt KF, Nerlich AG: Classification of age-related changes in lumbar intervertebral discs. 2002 Volvo Award in basic science. Spine (Phila Pa 1976) 27 (23): 2631-2644, 2002

5. Buckwalter JA: Aging and degeneration of the human intervertebral disc. Spine (Phila Pa 1976) 20: 1307-1314, 1995

6. Canbay S, Turhan N, Bozkurt M, Arda K, Caglar S: Correlation of matrix metalloproteinase-3 expression with patient age, magnetic resonance imaging and histopathological grade in lumbar disc degeneration. Turk Neurosurg 23(4): 427-433, 2013

7. Çetinalp NE: Servikal Dejeneratif Disk Hastalığında Matriks Metalloproteinazların Ekspresyonunun İmmünhistokimyasal Olarak Araştırılması (Uzmanlık Tezi), Ankara: Başkent Üniversitesi, 2007: 1-62

8. Eisenstein SM: Matrix metalloproteinases and aggrecanase: Their role in disorders of the human intervertebral disc. Spine (Phila Pa 1976) 25: 3005-3013, 2000

9. El Shazly AA, El Wardany MA, Morsi AM: Recurrent lumbar disc herniation: A prospective comparative study of three surgical management procedures. Asian J Neurosurg 8(3):139-146, 2013

10. Goker T, Dalgic A, Gurcan O, Gurcay AG, Tun MK: Nüks lomber disk hernilerinde tedavi yaklaşımları. Yeni Tıp Dergisi 30(2): 105-108, 2013

11. Gordon JL, Drummond AH, Galloway WA: Metalloproteinase inhibitors as therapeutics. Clin Exp Rheumatol 11 Suppl 8: 91-94, 1993

12. Goupille P, Jayson MI, Valat JP, Freemont AJ: Matrix metalloproteinases: The clue to intervertebral disc degeneration. Spine (Phila Pa 1976) 23: 1612-1626, 1998

13. Nerlich AG, Schleicher ED, Boos N: 1997 Volvo Award winner in basic science studies. Immunohistologic markers for agerelated changes of human lumbar intervertebral discs. Spine 22(24): 2781-2795, 1997

14. Pearce RH, Grimmer BJ, Adams ME: Degeneration and the chemical composition of the human lumbar intervertebral disc. J Orthop Res 5(2):198-205, 1987
15. Pfirrmann CW, Metzdorf A, Zanetti M, Hodler J, Boos N: Magnetic resonance classification of lumbar intervertebral disc degeneration. Spine (Phila Pa 1976) 26:1873-1878, 2001

16. Roberts S, Caterson B, Menage J, Evans EH, Jaffray DC, Eisenstein SM: Matrix metalloproteinases and aggrecanase: Their role in disorders of the human intervertebral disc. Spine 25(23): 3005-3013, 2000

17. Roughley PJ, Alini M, Antoniou J: The role of proteoglycans in aging, degeneration and repair of the intervertebral disc. Biochem Soc Trans 30: 869-874, 2002

18. Schroeder M, Viezens L, Schaffer C: Chemokine profile of disc degeneration with acute or chronic pain. J Neurosurg Spine 18: 496-503, 2013

19. Specchia N, Pagnotta A, Toesca A, Greco F: Cytokines and growth factors in the protruded intervertebral disc of the lumbar spine. Eur Spine J 11: 145-151, 2002

20. Takahashi H, Suguro T, Okazima Y, Motegi M, Okada Y, Kakiuchi T: Inflammatory cytokines in the herniated disc of the lumbar spine. Spine (Phila Pa 1976) 21: 218-224, 1996

21. Weiler C, Nerlich AG, Zipperer J, Bachmeier BE, Boos N: 2002 SSE Award Competition in Basic Science: Expression of major matrix metalloproteinases is associated with intervertebral disc degradation and resorption. Eur Spine J 11(4):308-320, 2002

22. WuWP, Jiang JM, Qu DB, Wei QZ, Jiang H: Expression of hypoxiainducible factor-1alpha and matrix metalloproteinase-2 in degenerative lumbar intervertebral disc. Nan Fang Yi Ke Da Xue Xue Bao 30 (5):1152-1155, 2010

23. Zhang Y, Sun Z, Liu J, Guo X: Advances in susceptibility genetics of intervertebral degenerative disc disease. Int J Biol Sci 4(5): 283-290, 2008

24. Zigouris A, Alexiou GA, Batistatou A, Voulgaris S, Kyritsis AP: The role of matrix metalloproteinase 9 in intervertebral disc degeneration. J Clin Neurosci 18(10):1424-1425, 2011

25. Zigouris A, Batistatou A, Alexiou GA, Pachatouridis D, Mihos E, Drosos D, Fotakopoulos G, Doukas M, Voulgaris S, Kyritsis AP: Correlation of matrix metalloproteinases- 1 and -3 with patient age and grade of lumbar disc herniation. J Neurosurg Spine 14(2):268-272, 2011 